recenze 



\section{Historie pravdivá Jana Augusty a Jakuba Bílka}

ČEJKA, Mirek, ed. Historie pravdivá Jana Augusty a Jakuba Bílka. Středokluky: Zdeněk Susa, 2018. 298 s. ISBN 978-80-88084-14-3.

Dílo, jež se nám v minulém roce dostalo do rukou, je důležitým dokladem myšlenek, tezí a názorů dvou členů Jednoty bratrské, mentora a jeho žáka i celoživotních druhů - Jana Augusty a Jakuba Bílka. Je dílem historiografickým, dílem memoárovým, dílem traktátovým, dílem polemickým. Zachycuje období kolem poloviny 16. století, kdy byli oba čeští bratří za své náboženské vyznání vězněni a mučeni na Pražském hradě a následně na hradě Křivoklátu, a umožňuje tak čtenáři nahlédnout do složité a spletité sítě náboženství a politiky.

Ústředním motivem raně novověké Historie pravdivé o některých zvláštních věcech a divných Božích skutcích v světě, obzvláště pak při Jednotě bratrské stalých od jednoho pobožného muže pro budoucí památku sepsaných a $v$ tento spis uvedených je snaha dvou českých bratří obhájit náboženské vyznání Jednoty bratrské, a opustit tak křivoklátský žalář. Duchovní boj jednotlivců s chodem českých dějin, které se zmítaly ve víru náboženských a společenských proměn, byl sváděn na třech frontách - výměna názorů probíhala jak s představiteli katolické církve a utrakvisty, tak později i se členy Jednoty bratrské (v důsledku napětí mezi Janem Augustou a dalšími českými bratry, kteří byli členy Úzké rady).

Editor Historie pravdivé - loni zesnulý pan docent Mirek Čejka - se díla chopil s cílem vytvořit čtenářské vydání textu studijní povahy. Mirek Čejka, absolvent českého a ruského jazyka na Filozofické fakultě v Brně, kde také od roku 1959 působil jako žáky velmi oblíbený učitel, již několik významných starších textů v minulosti editoval. Připomeňme si kupř́ikladu Gramatiku českou Jana Blahoslava (1991), kterou Čejka připravil společně s Dušanem Šlosarem a Janou Nechutovou, vydání souborů písní Adam Michna z Otradovic: Básnické dílo (1999), obsahující Českou mariánskou muziku, Loutnu českou a Svatoroční muziku; Dvě staročeská utrakvistická díla Jakoubka ze Stříbra (2009), případně z doby nedávné Čtyři menši spisy Jana Blahoslava (2013). 
Historie pravdivá je vydáním nejvěrnějšího opisu původního díla, který je součástí tzv. Cerroniho sbírky, jež se nachází v Moravském zemském archivu v Brně. Tento brněnský rukopis Historie pravdivé pochází z roku 1625 (autor opisu není znám), nicméně původní dílo bylo dokončeno již v roce 1579, bohužel se však nedochovalo. Jak Mirek Čejka ve své Zprávě editora v úvodu díla upozorňuje, pravopis rukopisu sloužil pouze pro foro interno, pro vlastní potřebu. Takový pravopis se vyznačuje balancováním na hranici postačující $k$ porozumění textu - a to $z$ důvodu užití pouze nezbytného repertoáru diakritických znamének a spřežek. Kritický aparát nese přívlastek redukovaný (s ohledem na již zmíněný čtenářský charakter textu), i přesto čítá přes 170 položek, jejichž jádrem je srovnání s tzv. roudnickým rukopisem, a to $\mathrm{v}$ případě, že se v roudnickém rukopisu vyskytuje jistá informace navíc, př́ípadně pokud dochází k rozdílu ve významu konkrétního sdělení. Práce editora také sestávala $\mathrm{z}$ vytvoření několika set vysvětlivek - nejčastěji se jedná o objasnění konkrétních dat (případně dalších časových údajů), historických událostí či reálií, vysvětlení archaismů a rozdílných významů slov oproti dnešku, odkazy na biblický text, výklad určitých frazeologismů - za pomoci výkladu Blahoslavovy Gramatiky, eventuálně připomenutí méně známých osobností 16 . století, které hrály v životech českých bratří, respektive i celé Jednoty bratrské významnou roli.

Editor Mirek Čejka čerpal nejen z již zmíněných rukopisů brněnského a roudnického, ale rovněž z rukopisu uchovaného v Praze v arcibiskupské knihovně a z nejmladšího opisu pocházejícího z roku 1815, jenž vyšel Krameriovým nákladem a je umístěn v Národním muzeu. Čejkova Historie je již čtvrtým vydáním Historie pravdivé: první bylo vydáno v Praze u J. Fetterlové v roce 1837 pod názvem Život Jana Augusty, staršího a správce jednoty bratrské v Čechách, sepsal Jan Blahoslav (ed. Josef Franta Šumavský). Druhá edice pochází z roku 1880 a vyšla pod názvem Život Jana Augusty čili vypravování o zajetí a uvěznění Jana Augusty a Jakuba Bílka v l. 1548-1564 (ed. Ludvík Bohumil Kašpar). Pod třetí edici se podepsal František Bednář, nese název Jan Augusta v letech samoty, Jakub Bílek a vydána byla v roce 1942 . Z roku 1895 pochází i překlad do němčiny, jejž editoval Joseph Th. Müller a vyšel pod názvem Die Gefangenschaft des Johann Augusta, Bischofs der böhmischen Brüder.

Historie pravdivá je rozdělena do 4 hlavních částí, tyto oddíly označil editor (pro lepší orientaci v díle) také v samotném textu. První část, skládající se z Bílkových vzpomínek, pravděpodobně uspořádal jeden nejvýznamnějších členů Jednoty bratrské Jan Blahoslav, jenž je na jejím konci také podepsaný. Úvod 
díla popisuje historický rámec, který ohraničuje události samotných pamětí, má tedy historiografický až kronikářský charakter, který postupně přechází $\mathrm{k}$ memoárové literatuře ( $\mathrm{v}$ tomto duchu se nese i část druhá, dělicím bodem je rok 1554), v jejímž ohnisku stojí právě pobyt českých bratří v křivoklátském vězení. Bílek v této části pojednává o historických událostech od šmalkaldské války a jejích důsledků pro Jednotu bratrskou přes popis průběhu uvěznění, výslechů a mučení českých bratří až po konečně propuštění, nejdříve Jakuba Bílka, později i Jana Augusty. Typickým rysem Historie pravdivé je pak převaha er-formy nad ich-formou a funkce takovéto výstavby narativu - mimo jiné je text v očích recipienta objektivnější. Příčina vzniku díla a jeho funkce je zřejmá: očištění od pomluv, které doprovázely životní dráhu Bílkova učitele a přítele, jenž se v jedné životní etapě odklonil od Jednoty bratrské.

Do struktury díla jsou dále zařazeny autentické dokumenty různého charakteru (polemického, reflexivního) spojené s Janem Augustou. Jedná se kupř́ikladu o „Vejpis artikulů Janovi Augustovi podaných leta 1560, jmenem Jeho Milosti Arciknížete podaných, chtěl-li by vězení prost byti, co by podniknouti a slíbiti měl“ a odpovědi na ně - jde o artikuly, které měl Jan Augusta přijmout za své a stvrdit je svým písemným souhlasem. V této kapitole se nachází konkrétně šest artikulů, které se zabývají mimo jiné Augustovým připojením k římské církvi, zákazem účasti na „pikhartských“ schůzkách, výkladem Písma a poslušnosti vůči církvi. Na každý ze šesti artikulů Augusta reaguje a ve formě traktátu je detailně rozebírá. Po obsáhlém pojednání o těchto artikulích následuje vypsání čtyř příčin, které objasňují Augustovo přiznání ke straně podobojí. Augustovy autentické polemiky a obhajoby, jež jsou vynikající ukázkou různých rétorických postupů s ohledem na adresáta sdělení, doprovází celou Historii pravdivou a spoluvytváří výsledný obraz osudů obou českých bratří. Tyto pasáže se navíc stylově liší od Bílkova rozsáhlého kronikářského a memoárového „výkladu“ událostí - který je však ozvláštněn i prvky beletrizačními. Poslední částí díla je pak „Rejstřík k snadnějšímu nalezení věcí v kníze této poznamenaných“, v níž autor zaznamenal pro snadnější orientaci v textu zásadní osoby a události v knize obsažené.

Oba čeští bratří snášeli své uvěznění v pokoře a zachovali si tak svou čest i víru. Jan Augusta i Jakub Bílek jsou po mnohaletých útrapách ze zajetí nakonec propuštěni - tím však jejich starosti nekončí, nebot Jednota bratrská právě procházela komplikovaným obdobím plným změn, než došlo k dočasnému uklidnění situace v poslední čtvrtině 16 . století. Bezprostřední nahlédnutí do jejich životů během tohoto těžkého období má nepochybně co nabídnout i dnešnímu čtenáři 
- nezbývá nám tedy než panu docentovi Mirku Čejkovi poděkovat za to, že nám zpřístupnil další významné literární dílo 16. století.

Jan Vašků 